\title{
The Impact of Salespersons' Interaction on Customer Satisfaction of Textile Shops: A Study in Kiribathgoda Area
}

\author{
P. Selvarajan ${ }^{1}$ \& M.L.J. Perera ${ }^{2}$ \\ ${ }^{1}$ Department of Economics and Management \\ Faculty of Business Studies \\ Vavuniya Campus of the University of Jaffna \\ SRI LANKA \\ ${ }^{2}$ Department of Textile Industry \\ Maligawatte, Colombo-10 \\ SRI LANKA \\ poongothai.selvarajan@gmail.com ${ }^{1}$, \\ jeewashani4@gmail.com ${ }^{2}$
}

\begin{abstract}
:-
All businesses are trying to win the market by competing with other rivalries. The Textile industry is not exceptional for that. Textile shops are also one of the well-known retail markets in the industry that depend on customer satisfaction for their success. The main objective of the study is to investigate the impact of salespersons' interaction on customer satisfaction of textile shops in the Kiribathgoda area since salespersons are the change agents to change the minds of customers. Data were collected through a structured questionnaire among 100 respondents based on the simple random sampling method. Researchers incorporated correlation \& regression analyses by using the SPSS version 20.0 software for analyzing the data. Major findings showed that all three dimensions of salespersons' interaction -Communication skills, Empathy and Trust have a positive relationship with Customer Satisfaction. 61.4\% salespersons' interaction impacted on customer satisfaction and Trust has a higher impact $(39.3 \%)$ on Customer Satisfaction rather than Communication skills and Empathy.
\end{abstract}

Keywords:- Communication Skills, Customer Satisfaction, Empathy, Salespersons' Interaction, Trust

\section{INTRODUCTION}

The textile shops come under the industry of textile, garment and accessories. This is one of the biggest industries in Sri Lanka. It plays a vital role in advancing the Sri Lanka's economy. Clothing is a basic need of all human beings and some people spend more money on garments than their food requirements. It was 
believed that clothing or garments was first developed even 650 thousand years ago. In today's context, the garment industry is a huge business that added more value to the world economy too. The wholesale clothing supply is increasing worldwide in all the sectors of the industry, whether it can be men's clothing, women's clothing, kids clothing and infant wear. In the textile, garments and accessories business, people can find many individuals and companies which are catering to the business needs of various levels given the value of modern fashion and trends.

\subsection{Research Problem}

In the textile shops salespersons are the employees who directly meet the customers and influence the minds of the customers. Due to the interaction between customers and salespersons is the essential factor for customer satisfaction and increase the sales (Gocek and Beceren, 2012). Hence, salespersons in every textile shop must consider about this factor for their business' success. They work in-between the company and the customers. They are the people who can build the relationship with customers. And also customers always try to measure the company service by evaluating the salespersons services (Basir et al., 2010). Salesperson is the person who can satisfy the customers by providing good service. In this study researchers try to find out how far the salespersons' interaction impact on customer satisfaction. Satisfaction is a phenomenon expressing that the performance and benefits of the products exceed the expectations of the customers (Peter and Olsan, 2005). Literature showed many factors which influence the customer satisfaction in the textile industry (Cuc, 2010). However, there is lack of literature related with the salespersons' interaction and customer satisfaction locally and globally. These literature opened avenues to motivate the researchers to do a study on how the salespersons' interaction impact on customer satisfaction.

\subsection{Objectives of the Study}

- To investigate how far the salespersons' empathy influence to satisfy the customers.

- To evaluate how far the salespersons' communication skills satisfy the customers.

- To identify the motivation methods of salespersons to improve the customer satisfaction.

\subsection{Literature Review}

There are external customers for business. Hence, every business always tries to understand about their customers mind. Salespersons are the internal 
customers for the business. Good interaction between customers and salespersons will provide support for easy of the transactions.

\subsubsection{Salespersons' Interaction}

Salesperson interaction is an important factor in the textile shops. They are the people who directly meet the customers and identify their needs. When buyers enter into the textile shop firstly they meet the salespersons. At once they catch the eyes of buyers, they welcome them and show their first impression towards them. Previous studies found out different factors related with customer satisfaction and salespersons' interaction ( Gocek and Beceren, 2012).

An empirical study on the relationship between sales skills and salesperson performance stated that many companies, salespersons are the most important marketing tool in the interface between the companies and their customers (Basir et. al., 2010). Baldauf and Cravens (2002) explained in their study of the effect of moderators on the salesperson behavior performance and salesperson outcomes performance and sales organization effectiveness relationship: operating at the interface between the organization and its environment, showed salespersons perform important boundary-spanning roles. Good salespersons may offer substantial performance improvements in today's increasingly competitive business environment. Futrell (2006) explained a top-quality salesperson who maximizes revenues from current existing customers and systematically identifies and manages new prospects well and which will allow a business entity to grow faster than its competitors.

The study of the effects of customer expectations and store policies on retail salesperson service, satisfaction and patronage exhibits in a retail store, services can encompass a variety of activities, including salesperson assistance, credit, gift wrapping and package delivery. Within those various activities, salesperson service is important to study (Stanforth and Lennon, 1997). Hence the impact of salesperson behavior is less clear and may have a significant effect on customer satisfaction and future patronage. Research of Reynolds and Beatty (1999) on customer benefit and company consequences of customersalesperson relationships in retailing shows that relationship generate benefits and value to customers were not only on satisfaction but also on loyalty. This research finding also showed that when consumer perceived social benefits and high functional, the consumer will be satisfied by salesperson. Gutman's (1982) study of a means-end chain model based on consumer categorization process indicated consumers choose products or services based on 
desired benefit. Reynolds and Beatty (1999) further stated that satisfaction with salespersons correlated to satisfaction with the company. They argued that customers' positive feelings towards their salesperson often transferred to the company. McMurry (1961) explained a successful salesperson to be a person who possessed a wooing is coupled by a "compulsive need to win and hold the affection of others". McMurry (1961) further identified some qualities of salesperson, such as a high energy level, self-confidence, a hunger for money, a well established habit for industry and a view of obstacles as challenges. A few years later McMurry's (1961) finding, Mayer and Greenberg (1964) showed that two basic qualities were essential in a good salesperson, such as empathy and ego drive.

Munshi and Hanji (2014) described in their study of A multidimensional subjective scale development for measuring sales performance of retail sales personnel within retail stores, salespeople are the main point of contact for customers and they are responsible for communication, store management, sales activities, solving customers' problems, helping them to make purchase decisions and thereby realizing sales closures and generating sales revenues.

The study of Ramayah and Leen (2013) on what drives relationship quality? A study of two retail clothing stores showed for the retail clothing stores, satisfaction and loyalty of a customer are no longer solely depending on the core product (it means apparel) they also on the service encounter which is the time when the customer interacts directly with the sales people and the store's elements. In this regard, it is vital for retailers to acquire knowledge of the factors that determine the relationship quality between service encounter and the customer, in the quest for customer loyalty. A company's success in being able to retain its customers will depend very much on how a company can successfully add value to its customers' shopping experience. The findings of Ramayah and Leen (2013) described trust and satisfaction were the two elements for the quality of relationship. Within their study they explained five variables which influence for the satisfaction such as physical aspects, reliability, personal interaction, problem-solving and policy.

Within their study they explained those five variables with the help of others studies. The study of determinations of relationship quality and loyalty in personalized services by Shamdasani and Balakrishnan (2000) exhibits Reliability and personal interaction and problemsolving are the social factors involving the salespeople who are within a store's environment. Reliability is viewed as a combination of keeping promises 
and performing the services right. Personal interaction involves two sub dimensions such as service personnel inspiring confidence and being courteous. Problem solving addresses the handling of returns and exchanges as well as complaints. Therefore, the service contact personnel's characteristics such as friendliness, confidence, honesty, expertise and knowledge of customers are important as they strongly influence relationship quality.

\subsubsection{Communication skills}

Within the textile shops transactions typically are initiated, maintained and completed on a person-to-person basis (Williams and Spiro 1985). The salesperson is the person who deals with customers interactively in a textile shop. The retail salesperson's most basic activity during this exchange is communication. Successful selling therefore depends on successful interpersonal communication. Scott (2005), explained communication is about sending, receiving, and understanding information and meaning. He showed that "receiving" and "understanding" are the most important operations in the communication process, since the response of the receiver defines whether the communication attempt is successful or not. He further defined two types of communication that are related to workplace communication; the effective and the efficient communication.

According to the study of Iksan et. al., (2012) on communication skills among university students' exhibits communication can be divided into two- the verbal communication and the nonverbal communication. Salespersons can also use verbal as well as non-verbal communication methods when dealing with their customers. Verbal communication means deal with customers by using words. Non-verbal communication includes body movements, voice qualities and physical distance between communicators. The study of Gabbott and Gillian (2001) showed that non-verbal communication channels cover the $70 \%$ or even the $90 \%$ of workplace communication. An exploratory study on relational selling strategy and key account managers' relational behaviors showed communication is of key significance in the relationship process between buyers and salespersons. It can be perceived as the main element of the satisfaction (Guenzi et al., 2007). (Oliver,1999) explored that loyalty of the business customer is based not only on product features but also on convergence of personal and social forces that exist between professional buyers and key contact personnel within supplier firms. The study of the link between salesperson job satisfaction and customer satisfaction by Homburg and Stock (2004) highlighted the role 
of key contact personnel in satisfying customers in the business market is an important factor. According to the study of Mohr and Nevin (1990) showed that communication processes underline most aspects of organizational interaction and therefore, are typically viewed as being critical to organizational success.

\subsubsection{Trust}

The study of Swan et. al., (1999) explained the development of trust between salesperson and their customers has traditionally been considered a critical element in developing and maintaining a successful sales relationship. The trust a customer has in a salesperson is generally thought to be a key determinant of the quality of their relationship. They further showed that customer trust of the salesperson has two components, affective and cognitive. Affective component explains the feeling of secure or insecure about relying on the salesperson, and cognition is the belief that the salesperson has both the necessary competence and motivation to be relied upon. A customer is any person who had, or can have some interaction with a salesperson or salespersons. According to the study of Customer - sales associate retail relationships explained customer trust in the salesperson is defined as a trust belief by which the salesperson can achieve long-term profit from customers (Beatty et.al., 1996).
Customer trust in the salesperson could increase through repeating deals between the salesperson and customer in which the salesperson seems to be rational, suitably honest, fair, responsible and charitable. The study of Chen and Mau (2009) also supported the above finding in the insurance industry. The trust affects on the loyalty of customers. Therefore, how to create and keep customers' trust in the salesperson and the company is a vital factor to develop a longterm relationship with the customers which leads to the customer satisfaction and retention.

Studies show that productivity, income, and profits are positively or negatively impacted depending on the level of trust in the work environment. Trust can be created or destroyed through personal perceptions and behaviors. It is predicated on who we are and how we are raised and is shaped by our experiences and perceptions of others' behavior (Anderson et.al, (1994).

\subsubsection{Empathy}

Bush et. al., (2001) defined the term empathy as the capability of visibly defined project for the trust of others, to attain and visualize the appropriate assessment of other's beliefs, attitudes and behavior. Davis (1983) also describes empathy in his study of measuring individual differences in empathy: evidence for a multidimensional approach as the response of person towards 
the acknowledged experiences of others. Based on the study of Empathy development, training and consequences by Goldstein and Michaels (1985) response spread specify two ranges, such as cognitive and local response that is considered as the expertise to be familiar with thinking, emotions and objectives. McBane (1995) explained second type of response within his study of Empathy and the salesperson: A multidimensional perspective, as the psychological response to others. The study of how to measure service orientation by Hogan and Hogan (1984) described the significance of empathy in buyer- seller interaction has been accepted. Ramsey and Sohi (1997) showed mostly results were linked with the influence of empathy on interactions with customers. Effective interpersonal listening and personal selling by Castleberry and Shepherd (1993) conclude that there is a positive relationship between empathy and interactional procedure of workers and consumers. The study of the link between sales people's job satisfaction and customer satisfaction in a business-to-business context: A dyadic analysis by Homburg and Stock (2004) explained lower levels of worker empathy leads to weaker interactional levels of worker and customers and that leads to less customer satisfaction. Furthermore in his study, he described the variable of empathy plays a mediating role between the job satisfaction of workers and Customer satisfaction. The greater degree of empathy of salespersons stimulates the relation of job satisfaction of salespeople and consumer satisfaction. Splauding and Plank (2007) described in order to build and maintain long term profitable customer relationships it is important that salespersons are empathetic towards their customers. In their studies showed that Empathetic salespeople are better able to understand customer's situations by putting themselves in their customer's positions. Further more in doing so, salespeople are better able to understand and recognize customer concerns cognitively and emotionally. The study of Salesperson adaptive selling behavior and customer orientation: A meta- analysis by Franke and Park (2006) found out that the salesperson is more able to customize their product solutions to satisfy customer needs and wants. According to the study of examining the effect of salesperson behavior in a competitive context by Ahearne et. al.,(2007) showed when customers feel that salespeople are empathetic towards them, customers are likely to feel that salespeople care about their points of view and are not just trying to sell their products or services. The studies of Conway and Swift (2000) and Wang (2007) exhibited therefore, salespeople who have higher levels of empathy have fewer barriers to overcome in developing customer satisfaction. 
The study of Greenberg and Greenberg (1983) explored when customers feel that salespeople are empathetic towards them, they feel more confident that the salespeople have a better understanding of their concerns and problems.

\subsubsection{Customer satisfaction}

Usually, all the persons have some expectations about whatever situation faced by them. As a customer he/she also has some expectation when they get the goods or services. If the good or service provider cannot meet their expectations, the customers will not satisfy. Salesperson must find out the importance of the customer satisfaction. In the textile, garments and accessories industry also consider the customer satisfaction as important factor for their success. Generally customers go to textile shops for buying garments. At that time quality of garments and salespersons performance is very much important factor to determine customer satisfaction.

According to the study of 'The importance of customer satisfaction in retention to customer loyalty and retention' by Singh (2006) described satisfaction is an overall attitude towards a product provider or an emotional reaction to the difference between what customers expect and what they actually receive regarding the fulfillment of a need. Kotler (2000) also defines satisfaction as a person's feelings of pleasure, excitement, delight or disappointment which results from comparing a products perceived performance to his or her expectations. According to Hitt et al.,(2007) the ultimate objective of the organizations nowadays is to satisfy a cluster of target customers with the help of competitive advantage due to the returns achievement are possible through building profitable relationships with customers and is considered the lifeblood of operating firms.

A study of the relationship between customer satisfaction and willingness to pay' by Homburg et. al., (2005) concluded that customer satisfaction significantly affected consumers' motivation to pay. Higher customer satisfaction results in repeat/frequent purchases.

Moreover, the findings of Day (1994) in his study of the 'capabilities of market-driven organizations' concludes that consumer satisfaction leads to higher level of consumer retention while the study of customer satisfaction as an antecedent of price acceptance by Huber et. al.,(2001) asserts that customer satisfaction is associated with willingness of customers to pay higher prices. In the above stated literature, various factors impact on the interaction between salesperson and customer satisfaction. The study of Evanschitzky et al.,(2012) show that adaptive 
selling and employee satisfaction positively impact on customer satisfaction. An empirical study of Zia and Akram (2016) found three variables which were salesman's ethical behavior, listening behavior and customer orientation impacted on customer satisfaction in packed milk industry in Pakistan.

However, researchers selected three factors under salesperson interaction dimensions after reviewing the literature carefully - the Communication skills, Trust and Empathy which are more relevant to Sri Lankan context and by using these factors examine how these factors impact on customer satisfaction.

\section{METHODS}

\subsection{Conceptual Framework}

Concepts or Constructs are ideas that represent the phenomenon.

Independent variable

$$
\begin{aligned}
& \text { Salesperson interaction } \\
& \text { - Communication skills } \\
& \text { - Empathy } \\
& \text { - Trust }
\end{aligned}
$$

The conceptual framework consists of concepts that are placed within a logical and sequential design. By considering about the literature review, researchers developed the conceptual framework. The study concerns about the concepts of salespersons' interaction and customer satisfaction. The researchers used three dimensions (communication skills, empathy and trust) under the salespersons' interaction as independent variable and the customer satisfaction is considered as the dependent variable. The conceptual framework shows the relationship between those three dimensions and the customer satisfaction. By using the following conceptual model (see Figure1) researchers explained the relationship between independent and dependent variables.

Figure 1: Conceptual Framework

Source: Adopted from Stanforth and Lennon, (1997) Williams and Spiro (1985), Swan et. al., (1999), Homburg and Stock (2004) \& Singh (2006)

\subsection{Sampling Plan}

Sampling is a process of selecting a subset of randomized number of members of the population of a study and collecting the data. In this study, researchers' selected 10 popular textile shops in Kiribathgoda area on the basis of purposive sampling to increase the validity and the area is the home town of one of the authors. 
Thilakawardhana Textile shop, Kandy Textile shop, Osaka Textile shop, Nimalee Textile shop, Sunanda Textile shop, J Love Textile shop, Gamma Textile Shop, Bellro Textile Shop, City Line Textile Shop and Nile Textile Shop are among them.

\subsection{Data Collection Methods}

The research study focused on primary data. Researchers developed a questionnaire for data collection by including the five point Likert scale questions to measure the three dimensions (communication skills, trust and empathy) under the salespersons' interaction and the customer

satisfaction of the textile shops. As per the information given by the owners of the textile shops, the total number of customers per day in all 10 shops is 285 excluding the festival season. (25-40 customers per day in each shop) Researchers selected 100 as the sample size and the questionnaires were distributed and collected among 10 customers of each of the 10 textile shops based on the simple random sampling method.

\subsection{Data Analysis Methods}

Researchers used the SPSS Version (20.0) package to analyze the data which were received from the survey study. The researchers used the frequency tables to show the respondents profile. By using descriptive statistics, researchers considered the mean values of independent variables and identified the importance of those variables for dependent variable. However, this analysis is excluded in this paper. Researchers used the quantitative analysis techniques to analyze the data.

\subsubsection{Correlation Analysis}

Pearson correlation coefficient (r) is used to determine the strength and direction of the two continuous variables. By using this correlation analysis, researchers identified the relationship between the independent variables (communication skills, trust and empathy) and the dependent variable (customer satisfaction) in the study and tested the hypotheses.

\subsubsection{Regression Analysis}

Regression analysis is used for identifying the impact of independent variables on dependent variables. Under this analysis, researchers used the Beta value and significant value to identify the impact of salespersons' interaction on customer satisfaction. 


\section{RESULTS}

\subsection{Correlation Analysis}

Correlation analysis is a statistical analysis that defines the variation in one variable by the variation in another, without establishing a cause-and-effect relationship. The coefficient of correlation is a measure of the strength of the relationship between the variables; that is, how well changes in one variable can be predicted by changes in another variable. In this study, researchers used Pearson Correlation coefficient (r) to determine the strength and direction of the two continuous variables. Pearson Correlation coefficient ( $r$ ) can take values from -1 to +1 and size of the value of the coefficient indicates the strength of the relationship and sign $(-$ or +$)$ indicates the direction. If the correlation coefficient is 0 , there is no relationship between the variables. The Table 1 shows the correlation between the Salespersons' interaction dimensions and customer satisfaction.

\section{Table 1: Correlation results of salespersons' interaction dimensions and customer satisfaction}

\begin{tabular}{|c|c|c|}
\hline & & $\begin{array}{l}\text { Customer } \\
\text { Satisfaction }\end{array}$ \\
\hline $\begin{array}{l}\text { Customer } \\
\text { Satisfaction }\end{array}$ & $\begin{array}{l}\text { Pearson } \\
\text { Correlatio } \\
\mathrm{n} \\
\text { Sig. (2- } \\
\text { tailed) } \\
\mathrm{N}\end{array}$ & 100 \\
\hline $\begin{array}{l}\text { Communicat } \\
\text { ion } \\
\text { Skills }\end{array}$ & $\begin{array}{l}\text { Pearson } \\
\text { Correlatio } \\
\mathrm{n} \\
\text { Sig. (2- } \\
\text { tailed) } \\
\mathrm{N}\end{array}$ & $\begin{array}{l}.583^{* *} \\
.000 \\
100\end{array}$ \\
\hline Empathy & $\begin{array}{l}\text { Pearson } \\
\text { Correlatio } \\
\mathrm{n} \\
\text { Sig. (2- } \\
\text { tailed) } \\
\mathrm{N}\end{array}$ & $\begin{array}{l}.241^{*} \\
.016 \\
100\end{array}$ \\
\hline Trust & $\begin{array}{l}\text { Pearson } \\
\text { Correlatio } \\
\mathrm{n} \\
\text { Sig. (2- } \\
\text { tailed) } \\
\mathrm{N}\end{array}$ & $\begin{array}{l}.632^{* *} \\
.000 \\
100\end{array}$ \\
\hline
\end{tabular}

Note: $*$ and $* *$ indicate statistically significant coefficients, at the $5 \%$ and $1 \%$ levels respectively. (Source: Survey Data, 2020)

The above Table 1 shows the significant values of salespersons' interaction dimensions. Since these are less than 0.05 , researchers can predict the relationship between the salespersons' interaction dimensions and customer satisfaction. According to the above table, the significant values 
are 0.000 for communication skills and trust and 0.016 for empathy. All these values are less than 0.05 . Therefore, researchers can prove that there is a significant relationship between the salespersons' interaction on customer satisfaction in Textile shops in Kiribathgoda area.

By seeing the Pearson correlation values, researchers can infer the relationship between the three dimensions of salespersons' interaction and customer satisfaction. There is a positive correlation between communication skills and customer satisfaction (0.583); a positive correlation between empathy and customer satisfaction (0.241) and finally a positive correlation between trust and customer satisfaction (0.632). From the analysis, researchers found the communication skills, empathy and trust dimensions of salespersons' interaction have positive relationship with customer satisfaction.

\subsection{Regression Analysis}

In regression analysis, researchers first checked the fitness of good of the research model by using following model summary in Table 2. Since the adjusted $\mathrm{R}^{2}$ is more than 0.5 , the fitness of the model is confirmed.
Table 2: Regression Analysis for salespersons' interaction and customer satisfaction

Model Summary

\begin{tabular}{|c|l|c|c|c|}
\hline Model & R & $\begin{array}{l}\text { R } \\
\text { Square }\end{array}$ & $\begin{array}{l}\text { Adjusted } \\
\text { R Square }\end{array}$ & $\begin{array}{l}\text { Std. Error } \\
\text { of the } \\
\text { Estimate }\end{array}$ \\
\hline 1 & $.786^{\mathrm{a}}$ & .618 & .614 & .170 \\
\hline
\end{tabular}
skills, Empathy, Trust and Customer satisfaction

(Source: Survey Data, 2020)

The above table shows that the adjusted $\mathrm{R}^{2}$ value is 0.614 . That means $\quad 61.4 \%$ salespersons' interaction affected on customer satisfaction. It indicates that salespersons' interaction has higher impact on customer satisfaction than the other factors. The other factors such as physical aspects of shop, policies of the shop, consumer expectations etc. have only $38.6 \%$ of impact on customer satisfaction which supports the findings of previous literature (Gocek \& Beceren, 2012). 


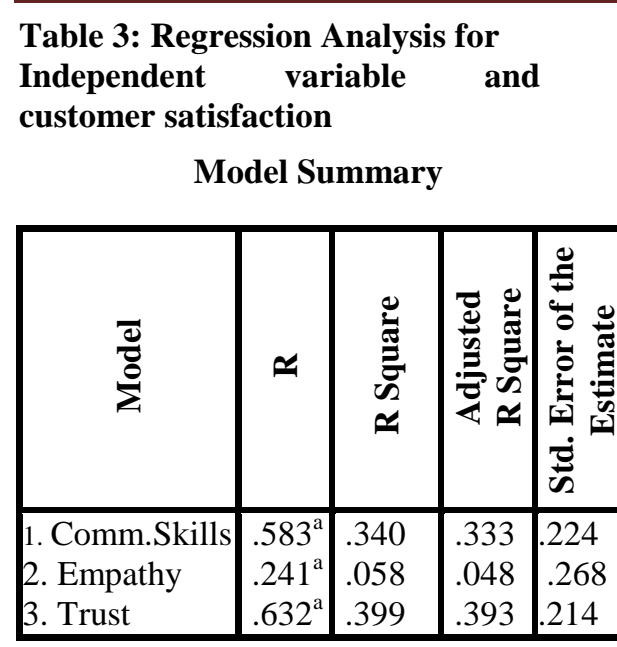

a.Predictors:(Constant),

Communication skills, Empathy,

Trust

(Source: Survey Data, 2020)

According to the data analysis, researchers analyzed the impact of Communication skills, Empathy and Trust on Customer Satisfaction individually. The Adjusted $\mathrm{R}^{2}$ value for communication skills is 0.333 , for Empathy 0.048 and for Trust 0.393 . That means $33.3 \%$ of communication skills, $4.8 \%$ of empathy and $39.3 \%$ Trust impact on customer satisfaction. Based on this analysis, Trust has higher impact on customer satisfaction rather than Communication Skills and empathy.

\section{DISCUSSION}

Based on the results the hypotheses $\mathbf{H}_{\mathbf{1}}, \mathbf{H}_{\mathbf{1 a}}, \mathbf{H}_{\mathbf{1 b}}$ and $\mathbf{H}_{\mathbf{1 c}}$ are supported to the salespersons' interaction and customer satisfaction. Summary of hypotheses testing is illustrated in Table 4.
Table 4: Hypotheses testing

\begin{tabular}{|c|c|}
\hline Hypotheses & $\begin{array}{c}\text { Supported/ } \\
\text { Not supported }\end{array}$ \\
\hline $\begin{array}{ll}\mathbf{H}_{1}- & \text { There is an } \\
& \text { impact of } \\
& \text { salespersons } \\
& \text { interaction } \\
& \text { on customer } \\
& \text { satisfaction } \\
& \text { of textile } \\
& \text { shops in } \\
& \text { Kiribathgoda } \\
& \text { area. }\end{array}$ & Supported \\
\hline $\begin{array}{c}\mathbf{H}_{\mathbf{1 a}} \text { - There is an } \\
\text { impact of } \\
\text { salespersons' } \\
\text { communicatio } \\
\text { n skills on } \\
\text { customer } \\
\text { satisfaction of } \\
\text { textile shops } \\
\text { in } \\
\text { Kiribathgoda } \\
\text { area. }\end{array}$ & Supported \\
\hline 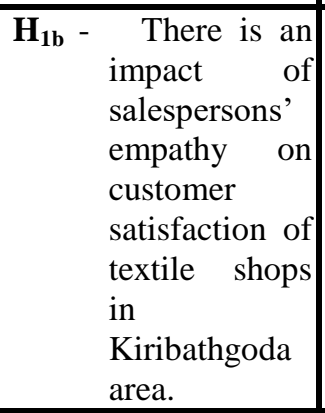 & Supported \\
\hline $\begin{array}{lr}\mathbf{H}_{1} \mathbf{c}-\text { There is an } \\
\text { impact } \\
\text { salespersons' } \\
\text { on } \text { Trust } \\
\text { satisfaction of textile } \\
\text { shops customer } \\
\text { Kiribathgoda area. }\end{array}$ & Supported \\
\hline
\end{tabular}

Source: Developed by researchers 


Researchers used correlation
analysis to explain the
relationship between the
salespersons' interaction and
Customer satisfaction. The
regression analysis was used to
explain the impact of
salespersons' interactions on
customer satisfaction. By using
the above analyses, researchers
explained that the findings were
supported by the previous studies
particularly the Hia was
supported by the findings of
Castleberry and Shepherd (1993);
the $\mathrm{H}_{1 \mathrm{~b} \text { is supported by the }}$
findings of McBane (1995) and
Spaulding and Plank (2007).
Finally the $\mathrm{H}_{1 \mathrm{c}}$ is supported by
the findings of the
predecessors Chen and Mau
(2009) and Ramayah and Leen
(2013).

\section{CONCLUSION}

Researchers considered the impact of salesperson interaction and customer satisfaction of textile shops in Kiribathgoda area in the present study. By doing this study researchers expect to find the impact of salespersons' interaction on customer satisfaction. And also researchers try to find out how the salespersons' interaction dimensions impact on customer satisfaction rather than other factors which are the physical aspect of the store, customer expectations, price etc.

By seeing the relationship results of salespersons' interaction and customer satisfaction, researchers concluded that all three dimensions of salespersons' interaction (Communication skills, Empathy and Trust) have positive relationship with customer satisfaction. That means, if the Textile shop's salespersons give high quality services by considering about all three dimensions, it leads to higher customer satisfaction. Therefore, the salespersons of the textile shops should try to give quality services by considering about the three dimensions for getting higher customer satisfaction. Moreover, this study shows the salespersons' interaction highly supported to customer satisfaction.

The salespersons of the textile shops should consider about the better relationship with the customers in every time because it highly support to customer satisfaction. If the customers cannot get fulfillment of their expectations from the Textile shops, they will not visit to that textile shop for purchases again and again. Since salespersons are one of the factors for attracting customers, they must pay attention on their qualities and how to interact with customers. 
Those three factors highly supported salespersons to build their interaction with customers and satisfy them. Finally, from this study researchers can derive to the conclusion that these three dimensions of salespersons' interaction leads to the customer satisfaction. Therefore, researchers can conclude that there is an impact of salespersons' interaction on customer satisfaction in Textile shops in Kiribathgoda area.

\subsection{Recommendations}

By conducting this study of the salespersons' interaction and customer satisfaction of Textile shops in Kirbathgoda area, researchers recommend the under mentioned considerations from the findings of the study to the interested parties. Researchers identified that the Textile shops in Kiribathgoda have given more importance for the communication skills and trust dimensions. By giving more consideration to these dimensions, they get higher the level of customer satisfaction. The empathy has less impact on customer satisfaction.

When considering the trust, they try to build a cordial relationship with customers. The salespersons always provide service which is matched with the customers' requirements. At that time salespersons can highly satisfy the customers. Salesperson should be a good friend for customers in the shop. If they promise to do a service, salespersons hurry to do this without time delay. Trust always binds with feelings. Salespersons should create relationship based on customer feelings hence the customers feelings and their behavior are different from person to person. Therefore, salespersons must understand customers mind and should build good relationship with them.

According to this study communication skills have an impact on interaction between customers and salespersons. From this study, researchers consider Communication skills are necessary to build good customer relationships and satisfaction. Basically salespersons have the ability to speak their native language correctly. Using mother tongue is one of the common and basic factors to create successful relationship. In Kiribathgoda area, most of the customers are speaking Sinhala. Salespersons are also fluent in Sinhala. It is an advantage for the Textile shops. Those Textile shops' salespersons have the ability to communicate with their customers correctly. In Kiribathgoda area textile shops, customers can understand the 
speaking way of the salespersons at once. This is the key point to the success of the shops. Salespersons body language and what they speak are similar. In case of shops in Kiribathgoda area, there is no difficulty for customers to understand the communication of salespersons.

Last dimension is empathy. This factor has low impact than other two factors. In the textile shop within Kiribathgoda area have huge customer base for the textile shops. Therefore, salespersons want to serve a large amount of customers. Due to this reason, salespersons could not pay attention for each and every customer. That is one of the weaknesses for the growth of the shop. Since there is a wide span of customer base, salespersons fail to understand customers' specific needs and wants. So they are unable to fulfill their needs. However, the opening hours are convenient to all customers. The customers of those textile shops always busy with their works. Hence, they expect and willing to shop at their free time. These shops are open until mid night. Therefore, customers can purchase garments after finishing their works. Salesperson is unable to be a guide to the customers all the time since they ought to deal with a pool of customers in the shops. Further, salespersons are unable to understand customers' personal interest and attitude regularly.
Therefore,

researchers recommend that salespersons should increase their other qualities like friendliness, expertise and confidence to get the higher customer satisfaction.

\subsection{Directions for Future Research}

Future researches can be extended to identify further factors except these three dimensions through an in-depth study and can do studies to identify the importance of those dimensions for salespersons' interaction in Textile shops by considering the large sample. For that, they can get the sample from all provinces in Sri Lanka or multiple areas in Sri Lanka. Future researchers can consider about cultural factors or demographic factors as moderate variables other than the salespersons' interaction dimensions which have impacted on customer satisfaction in textile shops. Moreover, this study was conducted prior to the COVID-19 pandemic situation in the country. Similar studies could be extended to understand the situation during the pandemic and post- pandemic period in Sri Lanka.

\section{REFERENCES}

Ahearne,M., Jelinek,R., and Jones,E.(2007).Examini ng the effect of salesperson service 
Selvarajan P., \& Perera M.L.J., Wayamba Journal of Management 12 (1)

behavior in a
competitive context,
Journal of
Marketing
603-616.
profitability: $\quad$ findings
from Sweden, Journal of
marketing, 58(3), 53-66.

Baldauf,A., and Cravens,D.W. (2002). The Impact of moderators on the salesperson behavior performance and salesperson outcome performance and sales organization effectiveness relationship, European Journal of Marketing, 36(11/12), 1367-1388.

Basir,M.S. Berhad,T.M. Ahmad, S.Z., and Kitchen,P.J. (2010), The relationship between sales skills and salesperson performance: An empirical study in the Malaysia

Telecommunications

Company International Journal of Management \& Marketing Research, 3(1), 51-73.

Beatty,S.E.,Mayer,M.,Coleman,J. E.,Reynolds,K.S., and Lee,J., (1996), Customer-Sales Associate Retail relationship, Journal of Retailing ,29(1), 59-74.
Anderson,E.W., Fornell,C., and Lehmann,D.R., (1994), Customer satisfaction, market share and

Bush,V.D., Rose,G.M., Faye,G., and Ingram,T.N., (2001), Managing culturally diversity buyer-seller relationships: The role of intercultural disposition and adaptive selling in developing intercultural communication competence, Journal of the Academy of Marketing, 29(4), 391404.

Castleberry,S.B. and Shepherd,C.D., (1993), Effective interpersonal listening and personal selling, Journal of Personal selling and Sales Management, 13(1), 35-49.

Chen,M.F and Mau, L.H (2009) The Impacts of ethical Sales Behavior on Cutomer Loyalty in the Life Insurance Industry, Service Industries Journal, 29(1), 59-74.

Conway, T. and Swift,T.,(2000),Internati onal relationship marketing: The importance of psychic 
Selvarajan P., \& Perera M.L.J., Wayamba Journal of Management 12 (1)

distance, European

Journal

Marketing,34(11/12),

1391-1409.

Cuc, S. (2010) A Managerial Approach of Customer Satisfaction Drivers in the Clothing Industry, Management\&

Marketing, 8(2), 334342.

Davis,M.H., (1983),Measuring individual differences in empathy:Evidence for a multidimensional approach, Journal of Personality and Social Psychology,44(2), 113-126.

Day,G.S. (1994),The capabilities of market-driven organizations, Journal of Marketing,58(2), 37-52.

Evanschitzky,H., Sharma,A., and Prykop,C (2012), The Role of the Sales Employee in Securing Customer Satisfaction, European Journal of Marketing, 46 (3-4), 489-508.

Franke,G.R., and Park,J., (2006),Salesperson adaptive behavior and customer orientation:A meta-analysis, Journal of Marketing Research,43(4), 455-463.
Futrall,C.M.,(2006),Fundamental s of Selling: customer for life through services(9th ed.),New York:McGrawhill Irwin.

Gabbott,M., and Gillian,H., (2001).The role of nonverbal communication in service encounters: A conceptual Framework, Journal of Marketing Management, 17, 5-26.

Gocek,I., and Beceren, Y,I. (2012). Assessments of the effects of Store Image, Perceived Risk and Customer Relations in the textile industry, International Journal of Business \& Social Science, 3(9), 133-145.

Goldstein,A.P., and Michales,G.Y., (1985) Empathy: Development, training and Consequences,Hillsdale, NJ: Erlbum.

Greenberg.H., and Greenberg, J. (1983). A new approach to the scientific selection of successful salesmen, Journal of Psychology,57 (Jna.), 113-123.

Guenzi,P., Pardo,C., and Georges,L., 
Selvarajan P., \& Perera M.L.J., Wayamba Journal of Management 12 (1)

(2007), Relational selling and key account managers' relational behavior: An exploratory study,Industrial

Marketing Management, 36, 121-133.

Gutman,J.,(1982),A means-end chain model based on consumer categorization process, Journal of Marketing,46(Spring),.6 0-72.

Hitt,M.A., Ireland,R.D., and Hoskission,R.E.,(2007), Strategic Management:competitiv eness and globalization, $\left(7^{\text {th }} \quad\right.$ ed), Mason,OH: South Western Publishing.

Homburg,C., Koschate,N., and Hoyer,W.D., (2005), Do satisfied customer really pay more? A study of the relationship between customer satisfaction and willingness to pay, Journal of Marketing, 70(4), 1-8.

Homburg.C., and Stock.R., (2004),Link between sales people's job satisfaction and customer satisfaction in a business-to-business context: A dyadic analysis, Journal of the
Academy of Marketing

Science, 32(2),144-

158. https://doi.org/10.11

77/0092070303261415

Huber,F., Herrmann,A., and Wricke,M.,(2001), Customer satisfaction as antecedent of price acceptance:results of an empirical study, Journal of product and Brand Management, 10(3), 160169.

Iksan,Z.H., Meerah,T.S.M., Osman,K., Lian,D.K.C., Mahmud,S.N.D., and Krish,P.,(2012),Commun ication skills among university students. Procedia:Social and behavioural science,17(1), 5-26.

Kotler,P.,(2000),Marketing Management, $\left(10^{\text {th }}\right.$ ed.) NewJersey: Prentice Hall.

Mayer,D., and Greenberg,H.M., (1964), What makes a good salesman?,Harvard Business

Review,42(July-August), 119-125.

McBane,D.A.,(1995),Empathy and the salesperson: A multidimensional 
Selvarajan P., \& Perera M.L.J., Wayamba Journal of Management 12 (1)

perspective,Journal of
Marketing,54(1), 36-51.
McMurry,R.N.,(1961),The
mystique of super-
salesperson, Harvard
Business Review,March-
April, 115-122.

Mohr,J., and Nevin,J.R., (1990), Communication strategies in marketing channels:A Theoretical perspective,Journal of Marketing, 54(4), 36-51.

Munshi, $\begin{array}{lr}\text { Hanji,S.,(2014), } & \text { A } \\ \text { multidimensional } & \\ \text { subjective reale } \\ \text { development } & \text { for } \\ \text { measuring } & \text { scales } \\ \text { performance of retail } & \text { rales personal, IOSR } \\ \text { sales } & \text { IOrnal of Business and } \\ \text { Journagement,16(4),39- } & \\ \text { Manas. } & \end{array}$

Oliver,R.L.,(1999), Whence customer Loyalty? Journal of Marketing, 63, 33-44.

Peter,J.P., \& Olsan, J.C., (2005). "Consumer Behaviour and Marketing Strategy", The McGraw-Hill

Companies,Inc., New York.

Ramayah,T., Leen,J.Y.A., (2013), What drives
relationship quality?A study of two retail clothing store,Journal of the Asian Academy of Applied Business,2(1), 33-43.

Ramsey,R.P., and Sohi,R.S., (1997), Listening to your customer:The impact of perceived salesperson listening behavior on relationship outcomes, Journal of the Academy of Marketing Science,25(2), 127-137.
Reynolds,E.K., and Beatty,D.E.S.,(1999),Cu stomer benefits and company concequences of customer-salesperson relationships in retailing, Journal of Retailing,75(1),11-32.

Scott,T.J.,(2005), The concise Handbook of manager:A parcticioner's approach,USA,The Haworth Press.

Shamdasani,P.N., and Balakrishnan,A.A., (2000),Deteminants of retationship quality and loyalty in personalized service, Asia Pacific Journal of Management ,(17),399-422.

Singh,H., (2006), The impact of customer satisfaction 
Selvarajan P., \& Perera M.L.J., Wayamba Journal of Management 12 (1)

relation to customer
loyalty and
retention,UCTI.WP-06-
06,May,Kualalumpur,
Malaysia.

Spaulding,D.G., and Plank,R.E.,(2007),Sellin $\mathrm{g}$ automobiles at retail:Is empathy important, Journal of Marketing Management, 17(2), 142155.

Stanforth,N.C., and Lennon.S.J., (1997), The effects of customer Expectations and store policies on retail salesperson service satisfaction and patrognage, Clothing and Textiles research Journal,15(2),115-129.

Swan, J.E., Bowers, M.R., and Richardson,L.D., (1999) Customer Trust in the Salesperson: An integrative review and Meta Analysis of of the Empirical Literature,
Journal of Business Research, 44(2), 93107.

Wang,C.L.,(2007) Guanxi Vs. relationship marketing :Exploring underlying differences, Industrial Marketing Management, 36 (1), 81-88.

Williams,K.C.,and Spiro, R.L., (1985),Communication style in the salespersoncustomer Dyad, Journal of Marketing Research,22(4), 434-442.

Zia, N.U., and Akram,M.W., (2016) Impact of Salesman Behavior on Customer Satisfaction: An Empirical Study of Dairy Retail Handlers, Kuwait Chapter of Arabian Journal of Business and Management Review, 5(8), 21-32. 